\title{
Male Violence against Women and Hybrid Identities in Post-Apartheid South African Black Theatre
}

\author{
Olga Barrios
}

Facultad de Filologia, University of Salamanca, 37008, Salamanca, Spain

\begin{abstract}
Post-apartheid black South African playwrights of both sexes claim the need to destroy apartheid's legacy and construct new spaces where women stop suffering violence at the hands of men and where they are not discriminated for being exponents of hybrid identities. However, since women are the central characters of the plays by both male and female playwrights, it seems evident that black women are portrayed as indisputable agents of social change in contemporary South Africa while demanding men's implication towards reaching the same goal. Therefore, this essay will analyze the pivotal role of contemporary black wo men playwrights in creating audience awareness geared towards social change; the depiction of black women's main concerns on suffering male abuse and violence and society's racist discrimination; and the ensuing struggle of black wo men to find their own space and dignity as women while asserting their identity as exponents of a new hybridized society in contemporary South Africa.
\end{abstract}

Keywords Male violence, Post-Apartheid South African Black Theatre, Hybridity, Women in South Africa, Women Playwrights

\section{Introduction}

Although some of the sequels of apartheid seem to being suffered more intensely by black and coloured[1] wo men in post-apartheid South Africa, and, in spite of the growing number of black female playwrights in recent times, it is noteworthy to observe that it is both male and female playwrights who are using the theatre space as a special platform from which to show their concerns and denounce these harmful sequels with the intention to contribute to social change. Two are the main issues repeated in contemporary black theatre plays: male abuse and violence against women and the discrimination that affects those people of hybrid identities (coloureds). In all cases, playwrights have chosen women as their central characters to expose and denounce a reality that still conveys the destructive effects of apartheid. In regard to the issue of the various types of male violence black women are exposed to - either in or outside the home, I will examine two plays that I consider best disclose and study this subject: WEEMEN (1996) by Thulani S. Mtsali and Kwa-Landlady (1993) by Magi Noninzi Williams Concerning the issue of discrimination suffered by people of hybrid identities, the coloured community specifically seems to continue suffering from not having their right place in contemporary

* Corresponding author:

barrios@usal.es (Olga Barrios)

Published online at http://journal.sapub.org/arts

Copyright (C) 2012 Scientific \& Academic Publishing. All Rights Reserved
South African society since they are "neither black nor white yet both".[2] More particularly, I will focus on coloured women, who best represent the double jeopardy they are subjected to for being women and coloured as portrayed in the plays by Malika Ndlovu, A Coloured Place (1996) and Is mail Maho med, Cheaper than Roses (1995).

In sum, as the most public and participative of all literary genres - and closest to African oral tradition, theatre has been chosen as the most suitable vehicle chosen by post-apartheid playwrights to expose the sequels left by apartheid on the South African population. Thus, theatre continues to be the favourite genre to be used to raise consciousness among people as it happened through the 1970s and 1980s during the Black Consciousness Movement. However, if during the Black Consciousness Movement it was almost exclusively male theatre artists who denounced the situation suffered by the black population under apartheid, in post-apartheid South African theatre, wo men seem to have taken the lead to condemn the abusive situations suffered by black and coloured women. On the one hand, playwrights claim the need to destroy apartheid's legacy and construct new spaces where wo men stop suffering violence at the hands of men and where they are not discriminated for being exponents of hybrid identities.[3] On the other, since women are the central characters of the plays by both contemporary male and female playwrights, it seems evident that black women are portrayed as indisputable agents of social change in contemporary South Africa while demanding men's implication towards reaching the same goal. Therefore, this 
essay will analyze the pivotal role of contemporary black wo men playwrights in creating audience awareness geared towards social change, and the adherence of male playwrights in that task; the depiction of black women's main concerns on suffering male abuse and violence and society's racist discrimination; and the ensuing struggle of black wo men to find their own space and dignity as wo men while asserting their identity as exponents of a new hybridized society in contemporary South Africa.

\section{Representation of Black Women in Post-Apartheid South African Theatre}

The names of black wo men playwrights from Africa and the African diaspora have become more and more prevalent in postcolonial theatre texts. In South Africa, concretely, it has been democracy after apartheid that has especially helped to catapult young black wo men playwrights into the public arena. In line with socio-political issues from the past, these young black female playwrights have grown more and more aware of gender and identity issues in their writing, specifically those of male violence against women and hybrid identities. Interestingly enough is to see that, parallel to female playwrights' concerns, there seems to be a growing number of male playwrights equally concerned about the same issues who show their support through the voices of central female characters in their plays.

Young South African playwright Malika Ndlovu (Lueen Conning)[4] refers to the specific case of black women playwrights in South Africa, and asserts that "although black female writers in South Africa have been active for a long time, they have been fairly invisible to the public eye, and those who have gained recognition through their work have been primarily exposed to international audiences. Most of them have yet to be acknowledged and supported at home" (Perkins 8).[5] There was a considerable absence of female playwrights during apartheid. Most of the plays were written, directed and performed by men, but the reason for their absence must be analyzed within the particular frame of the South African milieu and apartheid.[6] However, anthologies such as Black South African Women: An Anthology of Plays (1998) by Kathy Perkins include plays by Fatima Dike and Gc ina Mhlophe, as well as by younger voices such as Malika Ndlovu and Magi Noninzi Williams, which demonstrates that the number of black South African women playwrights is expanding.

When examining the trajectory of black South African women in theatre, it is necessary to consider the essential role played by the Black Consciousness Movement in the 1970s and 1980s in South Africa. At that time, theatre was used and regarded as one of the most appropriate platforms to teach and encourage the black community to rise and fight for their rights against western oppression and imperialis $\mathrm{m}$ as well as to let them know they had great traditions and ancestral origins that should be brought to light and be proud of.[7] Nevertheless, gender issues were not included in the agenda of the Black Consciousness Movement, and most of the theatre plays of the time were written, performed and directed almost exclusively by men Fatima Dike was the only wo man playwright to publish and produce a play in the 1970 s. However, there were other black wo men playwrights from abroad who, by the 1980s, had begun to exert an important influence on black South African women writers. This was the case of the African American poet and playwright Ntozake Shange and her play for colored girls who have considered suicide / when the rainbow is enuf (1976).[8] Likewise, the gender issues examined in Shange's play have become pivotal in the plays written in South Africa since the 1990s,[9] as observed in the plays by the South African women playwrights analyzed here and especially concerned with wo men's is sues after apartheid.[10]

\subsection{Male Abuse and Violence against Women: Thulani S. Mts ali's and Magi N. Williams' Plays}

As already stated, it has been primarily in the last years of apartheid and during the few years of democracy in South Africa that black South African playwrights have commenced to address specific gender issues that concern their society. However, when analyzing wo men's issues, the pioneering work on black feminism by African American theorists must be taken into consideration. African American feminist writers such as bell hooks, Audre Lorde and Barbara Christian have outlined a new concept of feminism that has widened and added new dimensions to the feminist concepts established by western white femin ism.[11] On the one hand, black feminism proposed to destroy parameters and assumptions taken by dominant cultures as well as to reclaim the lives of black women; on the other, black feminis m built new methods that helped explore how gender and race were intertwined while encouraging the foundation of a strong bond among black women. Furthermore, it has been African American feminists who actually have established the foundation for feminists to consider and study the subject of difference.[12]

Following the line of black feminist thought established by African American women, non-western black femin ist theorists have expanded it by beginning to examine the issues of gender and race within the realm of their own countries. They have demonstrated that it is crucial to draw attention to each country's specific regional and socio-political matters when addressing specific women's is sues. One of these critics has been Miranda Davies who in her book Third World, Second Sex has focused precisely on the importance of those particular differences through a collection of interviews with women from countries previously colonized. By listening to those women, Davies emphasizes that most of their priorities were related with survival strategies rather than with explicit women's 
concerns.[13] Similarly, in the case of the few black South African women involved in the performing arts during apartheid, feminist issues were not their main target either, as theatre critic Lizbeth Goodman has observed: "I spoke to many women working in South African theatres, and most concurred with my simple hypothesis: that feminis $m$ was not the hot potato it is elsewhere, perhaps because racial, economic, and other 'larger' political issues took precedence" (Goodman 7).[14] It has been only after democracy was established in South Africa in 1994 that gender issues have commenced to pervade black South African plays,[15] as also noticed by Goodman: "One of the most striking observations to be made about gender, next to the politics of performance, is how rarely and partially gender issues have tended to be represented in South African culture and theatre. Race has, understandably, tended to take political priority. Now that there is more room for gender in the national agenda there is a significant space opening up for other issues and debates" (2). Theatre is being used by black wo men for many different purposes, such as teaching the black and coloured communities how to vote or to help them understand the meaning of democracy. Goodman considers that this is a theatre staged for a purpose, "to encourage self-empowerment among marginalized individuals, black and 'coloured' people in South Africa, including many wo men", while operating also as a political and feminist tool(7)[16].

In addition, it is significant to notice how gender awareness have equally begun to permeate the works by contemporary black South African male playwrights, especially on the issue of violence against women and on women's hybrid identity as part of the legacy left by apartheid and still unsolved in South African society. The fact that black male playwrights are adhering to black female's concerns needs to be especially highlighted since African women writers do not consider that those concerns should be regarded exclusively as a wo man's crusade but as a global struggle that must involve both sexes. In this sense, Nigerian writer Chikwenye Okonjo Ogunyemi maintains that African women's politics "has emphasized the interdependence of the sexes as a womanist ideal" (1996:104) - Ogunyemi has adopted Alice Walker coined term for black femin ism (womanis $m$ ) and has applied it to the particular needs observed in Africa The same can be said of Afro-Caribbean writer and critic Carol Boyce Davies who has equally highlighted that womanis m needs to recognize "a common struggle with African men against foreign domination" asserting that this kind of feminis $m$ is "not antagonistic to men" (qtd. in Assiba D'Almeida 13).[17] Similarly, Nigerian critic Molara Ogundipe has also observed that "few African men will oppose the concept of including women in the social transformation of Africa which is really the issue. Women have to participate as co-partners in social transformation. I think that femin ism is the business of both men and wo men anywhere in Africa" (229-30).

In the same line, Lesley A. Foster, founder of the
Masimanyane Women's Support Centre in East London, South Africa, considers it imperative that men get involved in social programmes to eradicate violence against wo men:

It is necessary for appropriate bodies to conduct an audit of work being done on men and masculinities. All people involved in men's programmes should be drawn together at a national forum to discuss the crises in this area and in relation particularly to violence against women, to identify the critical issues and to decide on the focus of work that should be embarked upon. There has to be an understanding that men must take responsibility for shaping their own agendas but that they should be a partnership with women's groups in addressing the problems which men and women face. Men too suffer from the traumas of the past, and appropriate acknowledgement is necessary (5-6. My emphasis).[18]

Accordingly, as shown in their plays, black South African male play wrights seem to have listened to women's pleas, remaining at their side and asserting that women's issues and concerns are actually social issues whose change affects both men and women. Among these new young male and female South African playwrights are the playwrights analyzed in this essay: Malika Ndlovu, Magi Noninzi W illiams, Is mail Mahomed and Thulani S. Mtshali.

Nowadays, male vio lence against wo men in South Africa seems to be a central issue that continues to exist as a legacy of apartheid and needs to be examined and exposed by female and male playwrights in order to erad icate it. Ann L. Foster underscores that the influence of apartheid "in the present mindset of individuals, communities and society as a whole" as well as the pain of the past and its influence needs to be acknowledged in order to create a new social order that destroys the cycle of violence inherited from the past (1999: 4-5). In this regard, it is important to emphasize that three of the playwrights mentioned in this study decided to become writers after witnessing specific examples of abuse and/or sexual aggressions towards women and little girls during and after the years of apartheid. This is the case of Fatima Dike, Thulani S. Mshali and Magi Noninzi Williams. In an interview with Stephen Gray in 1977, Dike asserted that her entry into theatre was due to the "hearing of a brutal rape and murder by a migrant worker of a seven year old township girl, to which Dike responded by saying, 'I had something to say to my people about that"' (qtd. in Flockemann 1999: 17). Williams's theatrical career was equally influenced by a similar incident, the rape of an eleven-year-old girl: "A policeman interrogated the young girl [who had just been raped] in front of everyone in a very rough way. This was a turning point for me to write plays. It affected me deeply. The play [no title given] looks at the stig ma of rape that stays with you, and how it affects you throughout life" (qtd. in Perkins 159).[19]

If Dike and Williams were propelled by the brutal rapes to two little girls, Mtshali decided to take to the stage the experience of a woman close to his family whose husband used to be ruthless to her. It was in the 1970s when "it 
struck [him] that this abuse wasn't only happening with[his relatives], but also in many other families. .. [He] realized [that there] was something that [he] must write. After seeing $[W E E M E N]$, many people were surprised that a man had written this play - some were even suspicious. But in general, African men responded favourably to the piece" (qtd. in Perkins 102-03).[20] And the fact that Mtshali is a man is actually a good example for other African men to learn they must commit in the same struggle against the male violence black women are suffering in South Africa, for this is not just a woman's problem but a social problem that must be eradicated.

In 1999, South African A mbassador to the United States Sheila Sissulu, aware of the magnitude of apartheid's legacy in today's South A frica, showed her concern on "the rampant crime, poverty and unemployment suffered by the Black majority, the millions of Black people who earn less than a dollar a day, the fact that the average Black salary is one-tenth of the average White salary, the horrific problem of violence against women" (Randolph 3. My emphasis).[21] On the other hand, Charlayne Hunter-Gault in an article written in 2000 stated that "a tough new domestic-violence law has also recently been enacted" but "activists have been vocal about their worry that there hasn't been enough training for law-enforcement officers who have to implement the act". But the fact that "the new law extends the definition of domestic violence to include the elderly, gays, lesbians, children, parents, girlfriends and boyfriends has led advocates to[regard] the statute as 'progressive"'(3).[22] Williams in her play Kwa-Landlady has Linda say that "African women . . . are actually oppressed double . . By the law and by [their] men" (175). [23]

As already observed, black theatre in the post-apartheid period continues to be used as a platform to spread information, raise consciousness among the black community and promote social change. However, it has been only after apartheid that black women playwrights have begun to specifically address issues concerning women's unequal conditions and to condemn the different types of violence exerted by men against them. Thus, for instance, some statistics on the issue of violence against women in South Africa are voiced in Magi N. Williams' play, Kwa-Landlady (1993), when Linda talks to Ma-Cummings:

\section{LINDA}

You know Mama I don't know what to say to you. But I'm doing serious work. I'm not only doing TV shows. I also do theatre. We do children's theatre and do plays on abused women. For instance, do you know how many wo men are raped daily in South Africa? .... Two hundred women have been raped daily in South Africa for the past three years .... And only one in twenty rapes has been reported. . . Some are married women. Nurses, lady teachers, university students, schoolgirls, let alone child ren, it's sick. . . University students are usually gang-raped on their own campuses.... There's a stigma attached to being raped (173).[24]

In order to prevent and eradicate the violence and aggressions suffered by women in South Africa as described by Linda, Leslie A. Foster considers it essential to create special education programmes on human rights and values that encourage social involvement as well as to count on artists and community leaders to raise consciousness in South African society.

If Williams' Kwa-Landlady is a presentation of the playwright's concern with sexual aggressions suffered by wo men outside their homes (rape or sexual harassment), Thulani S. Mtshali's WEEMEN concentrates on the violence exerted by husbands against their wives at home - something that is also present in Malika Ndlovu's $A$ Coloured Place. Mtshali presents quite bluntly the ruthless violence a great number of black women receive from their husbands, at times simply because these men dislike the way their wives have cooked a meal or because they feel their manhood is threatened. In WEEMEN, Mlitshe tells Tsorarelo (his wife) when she tries to defend herself from her husband's stupid suspicions and accusations:

\section{MLITSHE}

(Throwing things at her). Woman ngiyalibeka! uyalibeka! I say one you say two! ... (He takes an axe wanting to chop her)... Is that what they taught you when I married you? ... I am the only man[25] here ... this mouth says the final word here ... you, you are just like this furniture! ... bloody damn shit. (104)[26]

When Tsorarelo suggests she could help in bringing money home by getting a job, he replies:

\section{MLITSHE}

No wife of mine is going to work, because one: I support you, two: next time you will be having a lot of friends and many lunch boyfriends ... We [men] see what [women] do ... how they flirt around behind their husband, so don't pretend to be better, you women are all bitches man! (105). [27]

Mlitshe impersonates a character whose behaviour represents a specific type of man that repeats in a considerable number of psychological studies when examining violence against wo men at ho me.

But, Mtshali allows Tsorarelo to express her feelings so that the audience (male and female) may understand the humiliation a wo man feels under such conditions:

TSORARELO. .. what is that I get from [my husband]? Constant abuse ... harassment, insults and beatings ... But why? ... Am I doing something wrong? ... What? ... Nothing! . . But just because I am a wo man and I am his wife ... But why is that most women suffer one way or another? (107).

Out of desperation, Tsorarelo considers suicide, then thinks of her children and discards this option; till she finally finds what she believes is the best solution to her problem: "Kill the bastard once and for all and live in peace! ... Even God will forgive me" —although she does not really do that (107).[28] Killing the oppressor is actually a literary metaphor employed by many women writers as a 
symbol of liberation for women from their burden of pain and the abuse they receive in real life.

In contrast to the abused wife who voices her desperation and final decision to end with her situation in Mtshali's play, in Ndlovu's A Coloured Place, it is the daughter, Brenda, who condemns her mother's passivity after years of suffering from her husband's beatings. The portrayal of this married wo man mirrors a great number of wo men in society who feel unable to leave their husbands and break their marital ties to stop oppression:

BRENDA [to her mother]

But Ma you can't go on like this forever. I can't. I'm spending my life being your bodyguard and he hasn't stopped hitting you in all these years. What makes you think he'll ever change? He doesn't need an excuse these days. You just have to look at him sideways and he says you're asking for it. ... Look at you man, Ma, what are you holding on for? So one day he can hit you so bad that the stitches and ice-blocks won't even help. Is that what you want, Ma? (18). [29]

What is interesting about this quotation is that Brenda portrays a new generation of women who will not accept what their mothers have borne for years. Brenda symbolizes the new black/coloured woman aware of women's unequal position in society who is determined to fight against it, showing she will never submit to such situation. In the same line, Magi N. Williams' Kwa-Landlady encourages black wo men's sisterhood and togetherness to fight for the same common cause, as Linda proclaims: "Let's fight against oppression. Let's fight for equal Rights! Let's demand fair treatment at work and with the law, and let's fight for equal pay", to which Ma-Cummins responds: "Power to wo men!" (175).[30] This ending reminds of African American playwright Ntozake Shange's for coloured girls which equally ends with women singing and dancing together, celebrating themselves as stated by the character lady in red: "i found god in myself \& i loved her / i loved her fiercely" (67).[31] On the other hand, Thulani S. Mtshali, throughout his play, seems to be exhorting men to change by showing that change is possible. The play ends with Mlitshe accepting Tsorarelo's rules and asking her for forgiveness: "From now on, if you forgive me for the last time, I will prove to you that I have changed ... I want to work for you" (112).[32] The end is, logically, open, but in that statement the author wants to create some space for men's reflection and transformation. Only by creating an adequate space in that process of change to acknowledge "past traumas" and heal the pain they had been subjected to during apartheid, will South Africans be able to eradicate violence in general and violence against women in particular (Foster 4).[33] And theatre could become a healing tool in that process since the stage can help suffering to be exorcised and pain alleviated; then, action can be taken to generate social change.

When examining violence against women as well as other is sues concerning women's discrimination and abuse, tradition is an essential component to be equally analyzed.
Actually, tradition is present in all the plays examined here and is displayed in two different variants. All women consider there are many valuable elements in their traditions that must be maintained and used in their plays to draw attention to their identity, such as storytelling - Nd lovu and Mhlophe consider it an essential part of their writing process (Perkins 1998: 8; Flockemann and Maxibuko 44).[34] But traditions equally enclose many sexist rules against women which are also exposed in their plays to encourage women to break with them. Thus, in Kwa-Landlady for instance, Williams defends a black woman's freedom to choose her destiny, but presents the hardships many times implied in such decision. Linda is an actress who works on TV at night and her neighbours assume they are "harbouring a prostitute" because the women they consider decent do not work at night (Perkins 168).[35] Actually, stereotypes embedded in tradition contribute to the justification not only of sexist practices but of violence against women as well, and Williams is telling her audience those stereotypes must be eradicated. People need to be open-minded to new societal changes that help improve the condition of people, and in this specific case, the condition of wo men. In the same line, Malika Nd lovu's A Coloured Place introduces a Woman who states that her "parents broke tradition too, by not forcing [her] to marry the boy",[36] adding: "Besides I wouldn't let them . . I just remind myself that they're talking about a part of my body as if it doesn't belong to me . . you have to dare to step outside" (16).[37] These statements demonstrate that black and coloured women are determined to fight in order to keep their freedo $m$ and independence.

\subsection{South Afric an Women's Hybrididentities: Malika Ndlovu's and Is mail Mahomed's Plays}

Parallel to the issue of violence against women is the playwrights' concern with women's hybrid identity, particularly coloureds that appear to be surrounded by ambiguous sentiments from both white and black communities. It seems that coloureds, as a hybrid community, could not truly fit under white rule during apartheid, nor under black rule after democracy was installed in South Africa. During the years of apartheid and in post-apartheid society coloureds have remained at the margins of the nation's body politic. In the opinion of literary critic Grant Farred, the coloured commun ity in most cases has fully supported the black liberation movements throughout South African history, whereas sometimes made "common cause with the rulers of the white state" (5).[38] The situation they have been forced to experience has obliged them to stand on one side or the other.[39] And this feeling continues to exist in the new democratic South Africa. Curiously enough, "coloureds symbolize the hybridity of the postcolonial condition, even if they cannot signal a 'postracial' discourse. This community has no history out of South Africa because they were produced in the (then non-yet) nation" (Farred 7).[40] During apartheid, it was the promulgation of the Population Reg istration Act 
in 1950 that divided friends, families, and communities "and constituted the coloured community as a politically and geographically ... constituency for the first time" (Farred 49).[41] In regard to their origins, an ENGLISH HISTORIAN character in Malika Ndlovu's A Coloured Place indicates that "Cape Coloureds originated from Khoi San, white and Oriental. Natal Coloureds are different in many respects from the bulk of Coloureds in the rest of the country. Their origins can be traced to three groups: Mauritians, St. Helenans and Euro-Africans" (14).[42] This short history class might give an idea of the wide range of variants found within the above mentioned community and the complex and delicate position they have occupied in their country.

Actually, the coloured community in South Africa is a good exponent of today's worldwide people's hybrid identities, even if there are still people who do not want to accept or wish to ignore this fact. According to Farred, "in nations that function according to the law or racial absolutes, the interstice is a precarious, embattled, under- and (frequently) unrecognized space" (1).[43] When hybridity is not accepted by society, it becomes the cause of great tribulations for people who remain in between two races since "the hybrid subject cannot be a full member of the nation, in either its black or its white instantiation; for the coloured constituency there are all too few differences between white rule and black governance" (Farred 2000: 2).[44] In the case of South Africa, during apartheid, coloureds were not completely accepted by whites, though they remained closer to white standards; nowadays, in a democracy governed by blacks, they seem not to be completely accepted by the black majority either, as one of the characters (Girl in a Taxi) explains in Malika Ndlovu's A Coloured Place: "It's the whiteness in us that black people can't accept and it's the blackness in us that whites can't accept. In the past we weren't white enough and now we can't get jobs cos we not black enough" (12).[45] This testimony reminds of the tragic mulatto figure as portrayed in African American literature, since mulattoes are neither black nor white and yet they are both; but, especially, mulattoes/coloureds are the physical reminder of the presence of a white colonization.[46] On the other hand, coloureds are also a reminder of the "frag mentation existing within communities" which is "indicative of the frag mentation of identity of individuals and the problems each of these fragmentations give rise to" (Foster 4).[47] The search for an identity that can shelter both sides as a whole, a new non-fragmented self that does not have to reject one or the other - a new space, is actually what these young post-apartheid playwrights are encouraging their audiences to seek and are actually creating with their playwriting.

Hybridity[48] or mestizoness is the feature that distinguishes those born from parents of different ancestry, which has established a solid foundation to dispute theories that defend the existence of a pure race and/or a pure culture. Factors such as immig ration all over the world have favoured the mixing of people from different descent. However, when referring to coloureds in South Africa, they might remind us of a tragic reality that took place in the past, as Grant Farred observes:

Hybridity results, the coloured body reminds us, from the violent, sexual encounter between the colonizer and the colonized, the oppressed and the oppressor. . Hybridity speaks of the power of the colonizer to create "new" physical communities, "new bodies" (pigmentations, textures of hair, or physiognomies previously unknown to the colonized and possibly even to the colonizer) out of the sexual encounter between the "West" and "the colonized" (3).[49]

Moreover, like some wo men play wrights in South Africa, Farred thinks that if South Africa is to obtain a symbolic wholeness, a national identity, must understand that the presence of coloureds is the result of historical different migrations each of them with different motivations, asserting that "colouredness, understood [in his study] as the accumulation of this hybrid community's unique experiences, history, culture, and traditions, cannot be erased, ignored ..., or incorporated unproblematically into 'blackness' or 'whiteness"' (9).[50] Consequently, as requested by Malika Ndlovu in A Coloured Place, Farred also claims a space/place of their own for the coloured community.

South African playwright Fatima Dike actually wrote in 1977 the play The First South African about a true event that took place in South Africa. In her play, Dike's exposes the absurdity of segregation laws under apartheid. It is the story of a young coloured man that ends up not finding a place, because he is asked to leave the black township -where his black mother lives - because, according to South African segregation laws, he must move to a coloured township. In the 1990s, other young playwrights have focused on hybrid identity again. One of those playwrights is Malika Ndlovu in A Coloured Place (1996) who addresses the issue of being coloured in an attempt to make people understand that being coloured is as beautiful as being black or white or Indian, for instance, and that they should accept and embrace themselves the way they are rather than try to deny their mixed roots. As Ndlovu puts it, the aim of [A Coloured Place] is to feed and stimulate the questioning about identity and the significance of where we come from, and why, as Coloured people, we've never acknowledged our roots. The play says out of this acknowledgement we can define our true identity, and be at peace with that. . . I want to shake the apathy within the Coloured community through this play and celebrate the potential and rich heritage we posses. . . [The play] is a voice for Coloured people and a chance to look at ourselves in the mirror (qtd. in Perkins 7).[51]

Ndlovu's play, then, challenges coloured people to look at and accept themselves the way they are, so that their children and their children's children will know of "a Coloured place not rotting with division and inertia but a Coloured place of power and diversity that they will not be 
ashamed to call...home" (qtd. in Perkins 20), as asserted by Tracey, one of the characters.[52]

On the other hand, Ismail Mahomed, in Cheaper than Roses (1995), intends to examine what apartheid has done to each individual and to society in general. The play deals with a coloured woman who feels neither black nor white "but is lost in between". It shows how this woman is "bounced around like a ball by policies of the old government and now comes back to take advantage of the policies of the new government". With his play Mahomed wants to show that apartheid "has not only brutalized her but also her family and all of[them] who have to be witness to their pain" (qtd. in Perkins 54).[53] If Ndlovu, in spite of showing in her play the hardships suffered by the coloured community, attempts to raise courage, self-acknowledgement and celebration of being coloured, Mahomed's play, through Betty's character, presents the strong damage apartheid has caused the coloured community who continues to feel at sea.

It is noteworthy the fact that in both plays the coloured characters are women. If the analogy to mu latto wo men who abound in African American literature is considered again, another parallelis $\mathrm{m}$ might be established here. There is evidence that during slavery times in the U.S. mulatto women were sometimes "targeted for sexual abuse". Although most slaves were vulnerable to being raped, it was the mulatto who "afforded the slave owner the opportunity to rape, with impunity, a woman who was physically White (or near-White) but legally Black". Moreover, there has been a myth about the mulatto woman who was described by white men as seductress "whose beauty drove White men to rape her" (Pilgrim 3)[54]. On the other hand, mulatto/coloured women symbolized various attributes, rape and concubinage and/or miscegenation; the colour line had been trespassed and, consequently, the prohibition of mixing races had been disobeyed by white men, the same who created the law. The plays seem to attract the audience's attention to the fact that these coloured women had suffered during apartheid under white power and still continue to suffer under black rule too for, as mentioned earlier, no space has been created by society to face and remove the pain of the past and accept coloureds just the way they are.

On the other hand, although both are a one-wo man plays, their structure and presentation equally differ. Ndlovu's $A$ Coloured Place uses a symbolic set that can be used to represent various locations - which parallels the diversity of the origins of coloured people celebrated by the author. The play is composed of a collection of sketches in which music and a screen for the projection of slides are used together with a variety of recorded voices that represent different characters, such as a social worker, a political speaker, gangsters, a news' reporter and so on. Mahomed, on the other hand, uses one only set - a railway platform at night - with only Betty's performance and voice to fill it in. Through Betty's memories and feelings we learn about her past life when she "chose to give up being a blerrie Coloured" (61)[55], and about her present mo ment:

\section{BETTY}

I did it once [passing] so why not again? (Kisses the ID book and throws it on to the railway tracks.) Goodbye ID. . . tomorrow I can apply for a new one. (Goes to pick up all her luggage.) One that says I'm just a South African and not a Coloured, White, African or an Indian. . . Mondays, a white... Tuesdays, a Jew... Wednesdays, a Coloured,... Thursdays, an exile and on Fridays, dronk en deurmekaar just like Betty Fourie. ... So, I'm going to walk on and you Mr. Mandela, maybe we'll meet again in the next town under better conditions (64).[56]

In spite of the humorous shades of this ending, it shows the internal struggle and split identity coloureds have suffered and still do suffer from. And the set of a railway station at night may symbolize the uncertainty and transition of a still unknown destiny for them.

\section{Conclusions}

It is evident, then, that black South African women playwrights have begun to use the stage as the perfect platform to place their demands, self-assertion and hope as well as they are leading male playwrights to write plays that support women's issues. As Malika Ndlovu asserts, black women "are faced with the enormous challenge of stepping into new territory in terms of what we have to say, what we believe needs to be addressed, and in defining and expanding our role in South African theatre" (qtd. in Perkins 8).[57] Or as Magi N. Williams observes, "[our] theatre is not only political, but it also touches on all different aspects of our diverse societies. Lastly, it creates a forum for debate. It makes people think" (qtd. in Perkins 160).[58] And when people are faced with thinking (as it was also done during the Black Consciousness Movement in the 1970s), after leaving the theatre house, they may begin or continue to bring change into their lives. Black and coloured South African playwrights have demonstrated with their work that they have already begun to transform their lives and shape their own destinies, and are helping to encourage other women and men to do the same. If during apartheid black writers were at the forefront of the struggle for the liberation of the black community, now black wo men playwrights have taken the baton in their race to find equal rights and to find their own voices. These women playwrights - followed and supported by male playwrights trough their own plays - and female characters are widening and enriching South African society by opening and presenting new gender perspectives, by revising and reconstructing their traditions, and by asserting the diversity of their identities.

\section{REFERENCES}


[1] The category of coloured was established during apartheid to separate and allocate South Africans in different regions. The term coloured, however, is still used nowadays and it could be taken as the symbol of a new hybridized society.

[2] Using the phrase coined by Werner Sollors in his book Neither Black nor White Yet Both: Thematic Explorations of Interracial Literature, Oxford University Press, USA, 1997.

[3] In regard to the new South African political situation, former South African Ambassador to the United States, Sheila Sissulu has asserted that, "though apartheid has been legally abolished, its legacy will take years to overcome". Laura B. Randolph, "South Africa's First Woman U.S. Ambassador", Ebony, vol.1, no. 1, p. 3, October 1999.

[4] In the article by Andrew Gilder, "A Place of Belonging", Luee Conning is referred to by her new artistic name, Malika Ndlovu. Andrew Gilder, "A Place of Belonging", Mail and Guardian, p. 5, December, 2000.

[5] Kathy A. Perkins, ed., Black South African Women: An Anthology of Plays, Routledge, England and USA, 1998.

[6] In the special issue on African Women Writers in African Literature Today, its editors (Eldred Durosimi Jones, Eustace Palmer and Marjorie Jones) detect other hindrances African women writers must face when compared to men: "Writing and education go hand in hand and for all kinds of sociological and other reasons the education of women in Africa lagged far behind that of men". Eldred Durosimi Jones, Eustace Palmer, Marjorie Jones, eds., "Editorial", African Literature Today, James Currey and Africa World Press, England and USA, p. 1, 1987.

[7] Theatre had already been used by Bertolt Brecht in Germany in earlier times and later by Augusto Boal in Brazil with socio-political purposes, geared to raise consciousness and help the dispossessed, and to cast some light about their rights. Black South African playwrights, actors and directors have acknowledged especially Brecht's and Polish director Jerzy Grotowski's theatrical, political and acting ideas to have influenced their works during the 1970s and 1980s.

[8] Shange's play added an unprecedented gender dimension to black theatre till that moment, enhancing the extraordinary power existing within black women. The influence of Shange's play has been acknowledged by black women writers worldwide.

[9] Another female South African playwright not examined in this essay is Fatima Dike (first female playwright to be published during apartheid in the 1970s). In Dike's So, What's New? (1991), for instance, she shows the strong bond that exists between different generations of black South African women.

[10] It is important to remember that black South African playwrights such as Fatima Dike and Gcina Mhlophe were already writing plays during the last phase of apartheid. At that time period, there was only one play created collectively and performed exclusively by black women under the direction of Phillis Klotz (You Strike the Woman, You Strike the Rock, 1981). However, it has been mainly in the 1990s when women (and also men) playwrights have begun to draw particular attention to women's issues in their society.

[11] Apart from the many articles written by hooks, Lorde and Christian, there are two specific studies on black feminism that have become a milestone in black feminist theory: bell hooks, Aint' I a Woman: Black Women and Feminism, South End Press, USA, 1981, and Barbara Christian, Black Feminist Criticism: Perspectives on Black Women Writers, Pergamon Press, USA, 1985.

[12] Avtar Brah expands on the issue of difference in the Introduction to her book. Avtar Brah, "Introduction", Cartographies of Diaspora: Contesting Identities, Routledge, England and USA, pp. 1-6, 1996.

[13] In the case of Mozambique's revolution, for instance, preoccupied with the problem of illiteracy, women organized special courses and developmental programmes to help women build certain skills. Miranda Davies, Third World, Second Sex, Zed Books, England, pp. 128-129, 1983.

[14] Lizbeth Goodman, ed., Women, Politics and Performance in South African Theatre Today. Contemporary Theatre Review, an International Journal, vol. 9, Part 1, pp. 1-88, 1999.

[15] Antecedents of women's issues can be found in the plays of more veteran female South African playwrights such as Gcina Mhlophe and Fatima Dike, though they did not focus so overtly upon them.

[16] Lizbeth Goodman, ed., Women, Politics and Performance in South African Theatre Today. Contemporary Theatre Review, an International Journal, vol. 9, Part 1, pp. 1-88, 1999.

[17] Irène Assiba D'Almeida, Francophone Women Writers: Destroying the Emptiness of Silence, University Press, Miami, USA, 1994.

[18] Foster, Leslie Ann, "Violence Against Women: The Problems Facing South Africa", International Planned Parenthood Federation, CHOG99, Durban, South Africa, 1999. Online Available: http://www.ippf.org/resource/gbv/c hogm $99 /$ foster.htm.

[19] Leslie Ann Foster, "Violence Against Women: The Problems Facing South Africa",International Planned Parenthood Federation, CHOG99, Durban, South Africa, 1999, Online Available: http://www.ippf.org/resource/gbv/c hogm99/foster.htm; Miki Flockemann and Thuli Mazibuko, "Between Women - An Interview with Gcina Mhlophe", Contemporary Theatre Review, An International Journal vol. 9, Part 1, pp. 41-52, 1999; and Kathy A. Perkins, ed., Black South African Women: An Anthology of Plays, Routledge, England and USA, 1998.

[20] Kathy A. Perkins, ed., Black South African Women: An Anthology of Plays, Routledge, England and USA, 1998. Just recently more and more men's groups have begun to appear in various parts of the world. In an interview on Spanish TV (Channel 4) a few years ago (2006), Portuguese Nobel Prize writer José Saramago considered that it should be men rather than women who protested and demonstrated against the violence men are exerting up on women.

[21] Laura B. Randolph, "South Africa's First Woman U.S. Ambassador”, Ebony, vol 1, no. 1, pp. 1-4, October 1999.

[22] Charlayne Hunter-Gault, "Freedom's Promise (South Africa)", Essence, vol. 1, no. 1, pp. 1-5, May 2000.

[23] Magi Noninzi Williams, Kwa-Landlady (Play), in Black South African Women: An Anthology of Plays, ed. by Kathy A. Perkins, Routledge, England, pp. 162-76, 1998. 
[24] Magi Noninzi Williams, Kwa-Landlady (Play), in Black South African Women: An Anthology of Plays, ed. by Kathy A. Perkins, Routledge, England, pp. 162-76, 1998. Statistics on the violence suffered by women in South Africa illustrates the seriousness of this issue as well as will shed light on why male and female playwrights want to use the stage as a platform to show their concern and make society, especially men, aware of this terrible situation.

[25] In Ndlovu's A Coloured Place, a Psychologist informs that "violence has become a symbol of manhood" (17). Malika Ndlovu (Lueen Conning), A Coloured Place (Play), in Black South African Women: An Anthology of Plays, ed. by Kathy A. Perkins, Routledge, England, pp. 9-22, 1998.

[26] Thulani S. Mtshali, WEEMEN (Play), in Black South African Women: An Anthology of Plays, ed. by Kathy A Perkins, Routledge, England, pp. 104-12, 1998.

[27] Thulani S. Mtshali, WEEMEN (Play), in Black South African Women: An Anthology of Plays, ed. by Kathy A Perkins, Routledge, England, pp. 104-12, 1998.

[28] Thulani S. Mtshali, WEEMEN (Play), in Black South African Women: An Anthology of Plays, ed. by Kathy A. Perkins, Routledge, England, pp. 104-12, 1998.

[29] Malika Ndlovu (Lueen Conning), A Coloured Place (Play), in Black South African Women: An Anthology of Plays, ed. by Kathy A. Perkins, Routledge, England, pp. 9-22, 1998.

[30] Magi Noninzi Williams, Kwa-Landlady (Play), in Black South African Women: An Anthology of Plays, ed. by Kathy A. Perkins, Routledge, England, pp. 162-76, 1998.

[31] Ntozake Shange, for coloured girls who have considered suicide/when the rainbow is enuf (Play), Bantam Books, USA, 1997.

[32] Thulani S. Mtshali, WEEMEN (Play), in Black South African Women: An Anthology of Plays, ed. by Kathy A. Perkins, Routledge, England, pp. 104-12, 1998.

[33] Leslie Ann Foster, "Violence Against Women: The Problems Facing South Africa", "Violence A gainst Women: The Problems Facing South Africa",International Planned Parenthood Federation, CHOG99, Durban, South Africa, 1999, Online Available: http://www.ippf.org/resource/gbv/c hogm99/foster.htm.

[34] Kathy A. Perkins, ed., Black South African Women: An Anthology of Plays, Routledge, England and USA, 1998; and Miki and Mazibuko, Thuli.n"Between Women - An Interview with Gcina Mhlophe”, Op. Cit Miki Flockemann and Thuli Mazibuko, "Between Women - An Interview with Gcina Mhlophe", Contemporary Theatre Review, An International Journal vol. 9, Part 1, pp. 41-52, 1999.

[35] Kathy A. Perkins, ed., Black South African Women: An Anthology of Plays, Routledge, England and USA, 1998.

[36] According to Esteban Beltrán, Director of the Amnesty International Spanish Section in Madrid, some groups of women are especially vulnerable to violence at home, such as domestics and women who have been forced to marry someone they did not freely choose. Seminar "Reality and Representation of Violence", held at the University of Salamanca, Spain, March 2000.

[37] Malika Ndlovu (Lueen Conning), A Coloured Place (Play), in Black South African Women: An Anthology of Plays, ed. by Kathy A. Perkins, Routledge, England, pp. 9-22, 1998.

[38] Grant Farred, Midfielder's Moment: Coloured Literature and Culture in Contemporary South Africa, Westview Press, USA, 2000.

[39] Throughout South African literary history, there are examples of coloured writers who have understood their identity in different ways, such as Richard Rive whose literary and political sentiments were mainly geared towards the issue of race, always standing next to blacks and fighting within the black liberation movements. On the contrary, Arthur Nortje's poetry shows "the uneven, demanding, and sometimes violent/psychic process by which coloureds attempt to accommodate themselves within black South Africa", and he has always defined himself as coloured, rather than aligning himself with blacks or whites. Another variation is the case of writer Jennifer Davids who, belonging to the generation of the Black Consciousness School, never aligned to it (Farred 57, 85, 94); but she never speaks openly about what she feels she is or which side she belongs to. Grant Farred, Midfielder's Moment: Coloured Literature and Culture in Contemporary South Africa, Westview Press, USA, 2000.

[40] Grant Farred, Midfielder's Moment: Coloured Literature and Culture in Contemporary South Africa, Westview Press, USA, 2000.

[41] Grant Farred, Midfielder's Moment: Coloured Literature and Culture in Contemporary South Africa, Westview Press, USA, 2000.

[42] Malika Ndlovu (Lueen Conning), A Coloured Place (Play), in Black South African Women: An Anthology of Plays, ed. by Kathy A. Perkins, Routledge, England, pp. 9-22, 1998

[43] Grant Farred, Midfielder's Moment: Coloured Literature and Culture in Contemporary South Africa, Westview Press, USA, 2000.

[44] Grant Farred, Midfielder's Moment: Coloured Literature and Culture in Contemporary South Africa, Westview Press, USA, 2000.

[45] Malika Ndlovu (Lueen Conning), A Coloured Place (Play), in Black South African Women: An Anthology of Plays, ed. by Kathy A. Perkins, Routledge, England, pp. 9-22, 1998.

[46] African American theorists have argued that the figure of the tragic mulatto was more myth than reality, except for some cases as that of actress Dorothy Dandridge, which was real. Still, David Pilgrim considers that "the mulatto was made tragic in the minds of Whites who reasoned that the greatest tragedy was to be near-White: so close yet a racial gulf away" (6), arguing that among the African American communities there have been many mulattoes who have been well-recognized and loved artists and leaders such as W. E. B. Du Bois, Langston Hughes or Malcolm X. David Pilgrim, "The Tragic Mulatto Myth", Ferris State University, Online Available:http://www.ferris.edu/JIMCROW/mulatto/.

[47] Leslie Ann Foster, "Violence Against Women: The Problems Facing South Africa", International Planned Parenthood Federation, CHOG99, Durban, South Africa, 1999, Online Available: http://www.ippf.org/resource/gbv/c hogm $99 /$ foster.htm.

[48] As an extended image that especially illustrates the societies of the 20th and 21 st centuries, hybridity is equally present in 
the performing arts. Western artists such as German playwright and poet Bertolt Brecht, found no complete satisfaction with western theatrical aesthetics and sought new venues, finding the perfect inspiration for his work in the Chinese Peking Opera. French theatre artist Antonin Artaud, equally uncomfortable with the realistic trend that prevailed in western theatre and wishing to transcend words, encountered in Balinese dances the new theatrical expression he was seeking. Polish director and playwright Jerzy Grotowski equally turned his look at Indian dances and performances; and Grotowski's poor theatre methods were adopted in turn by many black South African playwrights during the 1960s and 1970s and adapted to the South African distinctive reality. Equally, colonized countries took elements from the West while maintaining traditional ones, as is the case of South Africa. In this line, Brecht's and Grotowski's techniques were widely applied to black South African plays, combined with traditional African elements such as storytelling, poetry, music and songs or audience participation. For further information on the theatrical techniques used by South African playwrights see Olga Barrios, Commitment and Performance in Black South African Theatre Under Apartheid, New England Theatre Journal, Vol. 11, pp. 19-46, 2000.

[49] Grant Farred, Midfielder's Moment: Coloured Literature and Culture in Contemporary South Africa, Westview Press, USA, 2000.
[50] Grant Farred, Midfielder's Moment: Coloured Literature and Culture in Contemporary South Africa, Westview Press, USA, 2000.

[51] Malika Ndlovu (Lueen Conning), A Coloured Place (Play), in Black South African Women: An Anthology of Plays, ed. by Kathy A. Perkins, Routledge, England, pp. 9-22, 1998.

[52] Kathy A. Perkins, ed., Black South African Women: An Anthology of Plays, Routledge, England and USA, 1998.

[53] Kathy A. Perkins, ed., Black South African Women: An Anthology of Plays, Routledge, England and USA, 1998.

[54] David Pilgrim, "The Tragic Mulatto Myth", Ferris State University, Online Available:http://www.ferris.edu/JIMCRO W/mulatto/.

[55] Ismail Mahomed, Cheaper than Roses (Play), in Black South African Women: An Anthology of Plays, ed. by Kathy A. Perkins, Routledge, England, pp. 57-64, 1998.

[56] Ismail Mahomed, Cheaper than Roses (Play), in Black South African Women: An Anthology of Plays, ed. by Kathy A. Perkins, Routledge, England, pp. 57-64, 1998.

[57] Kathy A. Perkins, ed., Black South African Women: An Anthology of Plays, Routledge, England and USA, 1998.

[58] Kathy A. Perkins, ed., Black South African Women: An Anthology of Plays, Routledge, England and USA, 1998. 